\title{
Struktur Sel Streptokokus dan Patogenesis Glomerulonefritis Akut Pascastreptokokus
}

\author{
Sudung O. Pardede \\ Departemen Ilmu Kesehatan Anak FKUI-RSCM, Jakarta
}

Struktur sel streptokokus terdiri dari kapsul asam hialuronidat, dinding sel, fimbriae, dan membran sitoplasma. Kapsul asam hialuronat diperlukan untuk resistensi terhadap pagositosis dan perlekatan bakteri pada sel epitel. Dinding sel mengandung protein spesifik terdiri dari kelas mayor yaitu protein $\mathrm{M}$ dan protein $\mathrm{T}$ serta kelas minor yaitu protein F, protein R, dan M-like protein. Fimbriae pada permukaan dinding sel disusun dari protein $\mathrm{M}$ spesifik dan asam lipoteikoat (polifosfogliserol dan asam lemak) yang memediasi adesi Streptococcus pyogenes ke fibronektin pada sel epitel pejamu. Membran sitoplasma dibentuk dari lipoprotein. Streptokokus A dapat mengeluarkan eksoprotein yang bekerja sebagai toksin sistemik atau sebagai enzim invasif lokal seperti hemolisin yaitu streptolisin O dan streptolisin S, streptokinase, DNAse, serta proteinase seperti nikotinamid adenin dinukleotidase (NADase, adenosin trifosfatase (ATPase), fosfatase, hialuronidase, neuraminidase, lipoproteinase, dan eksotoksin pirogenik A, B, C. Berbagai antigen streptokokus diketahui berperan dalam patogenesis glomerulonefritis akut pasca streptokokus (GNAPS) meskipun mekanisme pastinya belum semuanya jelas. Biasanya GNAPS didahului infeksi saluran nafas atas atau infeksi kulit oleh kuman Streptococcus $\beta$ haemolyticus grup A. terjadi GNAPS melalui mekanisme 1. Pembentukan kompleks imun bersirkulasi dan terperangkap pada glomerulus, 2. Terdapat kemiripan molekul antara streptokokus dengan antigen ginjal, misalnya jaringan glomerulus normal bertindak sebagai autoantigen dan bereaksi dengan antibodi bersirkulasi yang dibentuk terhadap antigen streptokokus, 3. Pembentukan kompleks imun in situ antara antibodi streptokokus dan antigen glomerulus, 4. Aktivasi komplemen secara langsung oleh deposit antigen streptokokus dalam glomerulus. (Sari Pediatri 2009;11(1):56-65).

Kata kunci: streptokokus grup A, glomerulonefritis akut pasca streptokokus, protein $M$, neuraminidase

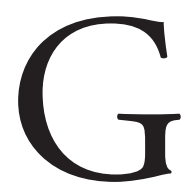

lomerulonefritis akut pasca streptokokus (GNAPS) pada umumnya didahului infeksi saluran nafas bagian atas atau infeksi kulit oleh kuman Streptococcus

\section{Alamat Korespondensi:}

Dr. Sudung O. Pardede, Sp.A(K). Divisi Nefrologi. Departemen Ilmu Kesehatan Anak Fakultas Kedokteran Universitas Indonesia Jl. Salemba no. 6, Jakarta 10430. Telepon: 021-3915179. Fax.021-390 7743. $\beta$ haemolyticus grup A dan kadang-kadang oleh grup C atau G. Galur yang dapat menyebabkan glomerulonefritis akut ini disebut streptokokus nefritogenik. ${ }^{1,2}$ Secara epidemiologis, $<2 \%$ anak yang terinfeksi streptokokus galur nefritogenik akan menderita glomerulonefritis akut, dan sekitar 5\%$19 \%$ di antara pasien yang menderita faringitis dan $20 \%$ di antara impetigo mengalami glomerulonefritis akut. ${ }^{3}$ Insidens GNAPS bervariasi sekitar 1\%-33\%, 
bergantung pada serotipe $\mathrm{M}$ serta tempat infeksi. ${ }^{2}$

Selain faktor kuman, terjadinya GNAPS dipengaruhi juga oleh beberapa faktor pejamu seperti umur, jenis kelamin, keadaan sosioekonomi, dan genetik. Lebih sering GNAPS dijumpai pada anak berumur antara 2-12 tahun, meskipun didapatkan $5 \%$ pada anak berumur $<2$ tahun. Laki-laki lebih sering daripada perempuan dengan perbandingan 2:1. Musim akan mempengaruhi kejadian GNAPS sebab infeksi tenggorokan lebih sering terjadi pada musim dingin dan awal musim semi, sedangkan piodermia lebih sering terjadi pada akhir musim panas dan musim gugur. Peran faktor genetik pada GNAPS terlihat dengan kejadian indeks kasus pada saudara kandung (38\%) yang lebih tinggi daripada anak dengan risiko epidemik (4-28\%). Pengaruh aspek genetik ditunjang dengan laporan penelitian mengenai hubungan kuat antara GNAPS dengan HLA-DR1 dan DRw4 sedangkan pasien dengan HLA-DRw48 dan DRw8 kurang rentan terhadap glomerulonefritis primer. ${ }^{2,3,4}$

Sejak tahun 1960-an, terdapat penurunan prevalensi GNAPS yang kemungkinan disebabkan oleh penggunaan antibiotik, peningkatan kondisi higiene masyarakat, perubahan potensi nefritogenik strain streptokokus, atau perubahan kerentanan pejamu. ${ }^{2}$ Meskipun telah diketahui bahwa GNAPS terjadi setelah infeksi Streptococcus $\beta$ haemolyticus, namun patogenesisnya belum jelas diketahui. ${ }^{2,3,4}$

\section{Kuman streptokokus}

Streptokokus dapat dibagi menjadi tiga kelompok berdasarkan kemampuan menghancurkan sel darah merah, yaitu Streptococcus $\beta$ haemolyticus jika kuman dapat melakukan hemolisis lengkap, Streptococcus $\alpha$-haemolyticus jika melakukan hemolisis parsial, dan Streptococcus $\gamma$ - haemolyticus jika tidak menyebabkan hemolisis 5,6,7 Streptococcus $\beta$ haemolyticus dapat dibagi menjadi 20 grup serologis yaitu grup A hingga T. Sistem penentuan serotipe grup A streptokokus dibuat menurut abjad berdasarkan jenis polisakarida dinding sel (Lancefield group) atas dasar reaksi presipitin protein $\mathrm{M}$ atau reaksi aglutinin protein $\mathrm{T}$ dinding sel. $5,6,7,8$ Disebut sebagai streptokokus grup A karena dinding sel terdiri dari polisakarida polimer l-ramnose dan $\mathrm{N}$-asetil-D-glukosamin dengan rasio 2:1. Polisakarida grup A ini mengadakan ikatan ke peptidoglikan yang disusun dari $\mathrm{N}$-asetil-D-glukosamin, $\mathrm{N}$-asetil-Dmuraminic acid, dan tetrapeptida asam d-glutamat, serta d- dan l-lisin pada dinding sel. Streptokokus grup A, B, C, D, dan G merupakan grup yang paling sering ditemukan pada manusia. Streptococcus $\beta$ haemolyticus grup A merupakan bentuk yang paling virulen. ${ }^{1}$ Streptokokus grup A disebut juga dengan Streptokokus piogenes, dan termasuk kelompok Streptococcus $\beta$ haemolyticus yang dapat menyebabkan GNAPS dan demam reumatik. ${ }^{1,7,8}$ Pada kuman streptokokus grup A ini, telah diidentifikasi sejumlah konsituen somatik dan produk ekstraselular, namun peranannya dalam patogenesis GNAPS belum semuanya diketahui. ${ }^{1,2}$

\section{a. Konsituen somatik}

Struktur sel streptokokus grup A terdiri dari kapsul asam hialuronidat, dinding sel, fimbriae, dan membran sitoplasma yang menutupi sitoplasma. Kapsul asam hialuronat bekerja sebagai strain mukoid, resisten terhadap pagositosis, dan berperan dalam terjadinya infeksi. Dinding sel merupakan struktur yang kompleks, terdiri dari protein spesifik, asam lipoteikoat, peptidoglikan, dan karbohidrat polisakarida grup A, serta mengandung berbagai struktur antigenik, dibentuk oleh polimer $\mathrm{N}$-asetil-D-glukosamin dan $\mathrm{N}$-asetil-D-muraminic acid yang dihubungkan oleh asam amino. Asam lipoteikoat dapat mempercepat kolonisasi kuman dan mengadakan ikatan dengan fibronektin pada permukaan sel epitel. Lapisan mukopolipeptida (peptidoglikan) berperan dalam rigiditas dinding sel. Selain mengandung komponen karbohidrat yang digunakan untuk membedakan streptokokus $\beta$ hemolitikus menjadi grup $A$, dinding sel kuman juga mengandung protein spesifik yang terdiri dari protein kelas mayor yaitu protein $\mathrm{M}$ dan protein $\mathrm{T}$ serta kelas minor yaitu protein $\mathrm{F}$, protein $\mathrm{R}$, dan $\mathrm{M}$-like protein. Streptokokus grup A mempunyai komponen dinding sel yang mempunyai peranan penting dalam perlekatan sel dan resistensi terhadap mekanisme pertahanan pejamu. Peranan berbagai protein permukaan sel yang terikat terhadap molekul fraksi Fc imunoglobulin belum jelas. ${ }^{1}$ Fimbriae yang menonjol pada permukaan dinding sel disusun dari protein $M$ spesifik dan asam lipoteikoat (polifosfogliserol dan asam lemak) yang memediasi adesi Streptokokus grup A ke fibronektin pada sel epitel pejamu. ${ }^{1}$ Membran sitoplasma dibentuk dari lipoprotein dan protein termasuk protein-terikat-penisilin (penicillin-binding protein) yang berperan dalam sintesis dinding sel, dan endostreptosin yang penting dalam patogenesis 


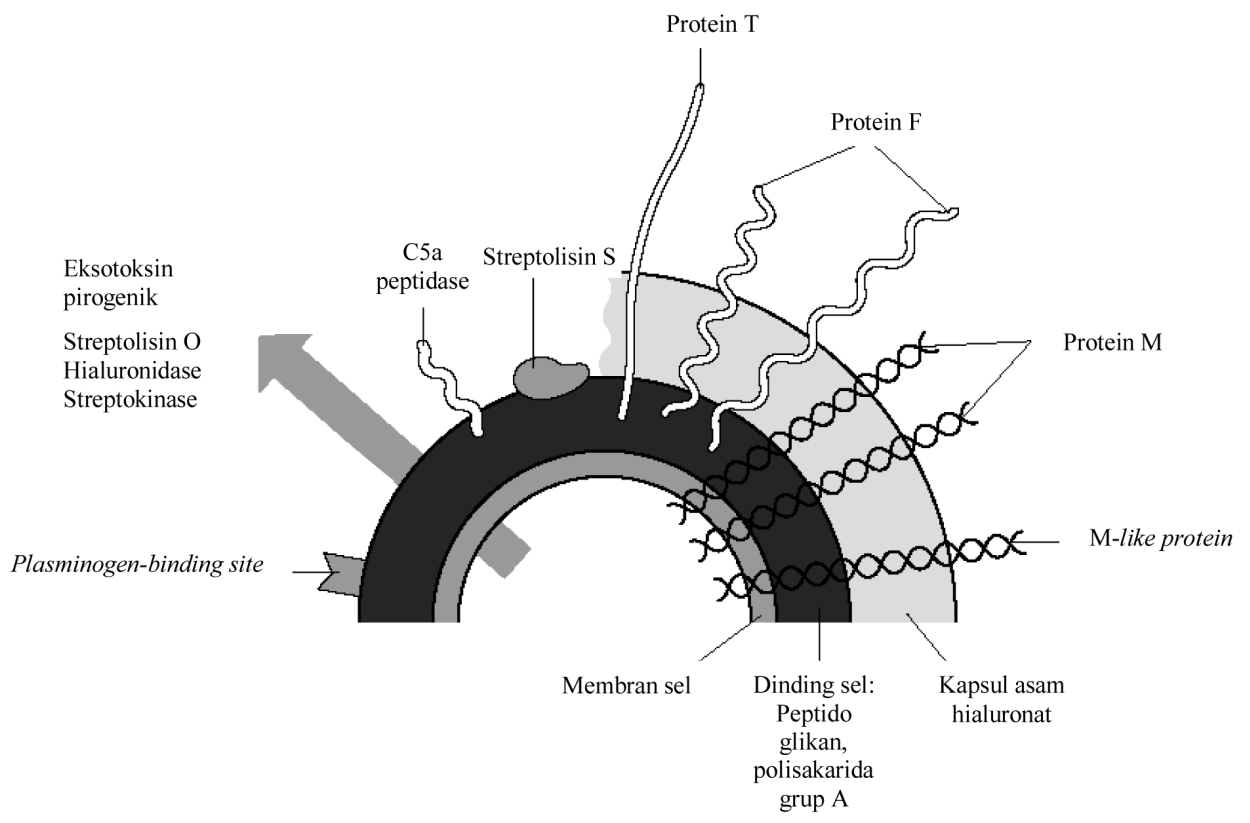

Gambar 1. Diagram skematik Streptococcus pyogenes

(Dikutip dan modifikasi dari Killian, 2005)

GNAPS. Di dalam sitoplasma terdapat DNA, RNA, serta berbagai bakteriofag. ${ }^{1}$

\section{Kapsul}

Streptococcus $\beta$ haemolyticus grup A diselubungi oleh kapsul yang terdiri dari asam hialuronat yang berfungsi untuk resistensi terhadap pagositosis dan untuk perlekatan bakteri pada sel epitel pejamu. Seperti kapsul kuman lainnya, kapsul streptokokus mempunyai efek antipagositik. Peran kapsul sebagai antipagositik di antara galur streptokokus berbeda-beda. Kapsul streptokokus identik dengan asam hialuronat jaringan ikat pejamu dan tidak imunogenik. ${ }^{2,6}$

\section{Protein M}

Streptococcus $\beta$ haemolyticus grup A, C, dan G mempunyai protein $M$ yang diidentifikasi lebih dari 80 serotipe. Protein $M$ merupakan faktor virulensi utama kuman Streptococcus $\beta$ haemolyticus. Gen yang menentukan banyaknya tipe protein $\mathrm{M}$ disebut dengan emm genes. 4,7

Protein $\mathrm{M}$ bersifat tahan panas, resisten terhadap pagositosis, dan sensitif terhadap tripsin. Protein $M$ terdiri dari 2 rantai dengan struktur sebagai alpha- helical coiled-coil dimer, yang tampak seperti rambut (hairy) pada permukaan sel kuman streptokokus., ${ }^{2,7}$ Protein M ini bermuara dalam membran sitoplasma, melalui dinding sel, dan menonjol dari permukaan sel sebagai fibril. Protein $\mathrm{M}$ mempunyai fraksi $\mathrm{N}$ terminal yang terdapat di bagian luar dan fraksi terminal C yang terdapat pada dinding membran sel dengan fraksi yang kaya prolin dan glisin yang melekatkan protein ke dalam dinding sel dan membran hidrofobik. ${ }^{2}$

Protein $\mathrm{M}$ dibagi menjadi dua kelas berdasarkan reaktivitas antibodi terhadap fraksi C. Protein M kelas I mengandung epitop yang terekspose dengan permukaan yang akan bereaksi dengan antibodi dan merupakan faktor-opasitas negatif, sedangkan protein $M$ kelas II tidak mengandung epitop dan tidak bereaksi dengan antibodi fraksi anti-C, serta merupakan faktor opasitas positif. ${ }^{2,7}$

Kemampuan resistensi Streptokokus grup A terhadap pagositosis oleh leukosit polimorfonuklear tergantung pada protein $\mathrm{M}$ permukaan sel. Resistensi terhadap infeksi Streptokokus grup A adalah hasil dari sekresi antibodi terhadap molekul protein M. Beberapa strain memproduksi 2 protein $M$ yang berbeda dengan aktivitas antipagositik dan secara struktural ada kaitan dengan M-like protein. Protein ini dapat berikatan dengan berbagai protein dalam serum pejamu termasuk 
plasminogen, fibrinogen, albumin, imunoglobulin $G$ (IgG), IgA, dan proteinase inhibitor $\alpha 2$-makroglobulin, serta beberapa faktor regulatori dari sistem komplemen seperti faktor $\mathrm{H}$ dan $\mathrm{C} 4$ b-binding protein. Faktor $\mathrm{H}$ mampu mendestabilisasi opsonin C3b jika mengendap pada permukaan bakteri. C4b-binding protein dapat menghambat pengendapan komplemen permukaan dengan merangsang degradasi $\mathrm{C} 4 \mathrm{~b}$ dan $\mathrm{C} 3 \mathrm{~b} .{ }^{6}$

Sifat nefritogenik Streptococcus $\beta$ haemolyticus grup $A$ ada kaitan dengan serotipe spesifik protein $M$, tetapi tidak semua strain serotipe protein $M$ bersifat nefritogenik. Umumnya protein M pada streptokokus penyebab piodermia dan infeksi farings adalah protein $M$ serotipe kelas II dengan kemampuan untuk memproduksi faktor opasitas, tetapi tidak mempunyai reaksi dengan antibodi terhadap fraksi C. ${ }^{2}$ Strain nefritogenik ini mempunyai protein $M$ serotipe $1,2,3$, $4,12,15,18,25,42,49,52,55,56,57,59,60$, dan 61. Terdapat perbedaan galur streptokokus penyebab GNAPS yang didahului infeksi farings dengan infeksi kulit. Glomerulonefritis akut pasca faringitis biasanya disebabkan protein $M$ serotipe 1,2, 3, 4, 12, 15, 18, 25, dan 49, sedangkan glomerulonefritis akut pasca piodermia pada umumnya disebabkan serotipe 2, 49, 52, 55, 57, 59, 60, dan 61. ${ }^{1,2}$ Protein streptokokus yang berikatan dengan pejamu yang mempunyai struktur yang homolog dengan protein M klasik disebut sebagai M-like protein. ${ }^{2}$

\section{Protein F}

Konsituen sel yang lain seperti protein $\mathrm{F}$ dan asam lipoteikoat mempunyai peranan penting dalam langkah pertama kolonisasi yaitu aderens Streptokokus grup A ke fibronektin pada permukaan sel epitel. ${ }^{7}$ Mekanisme utama kuman Streptokokus grup A untuk terikat dengan sel epitel farings dan kulit adalah berinteraksi dengan fibronektin pejamu yaitu suatu protein matriks pada sel eukariotik. Struktur yang dapat mengenali fibronektin pejamu terletak pada protein F, salah satu dari banyak protein pada permukaan kuman Streptokokus grup A. Interaksi antara protein $\mathrm{F}$ streptokokus dan sel fibronektin pejamu juga memediasi internalisasi atau masuknya bakteri ke dalam sel pejamu. Sebagai tambahan terhadap protein $\mathrm{F}$, asam lipoteikoat yang terpapar pada permukaan serta protein $M$ tampaknya berperan dalam perlengketan kuman dengan sel epitel mukosa dan kulit. ${ }^{6}$ Selain protein F, pada dinding sel kuman
Streptokokus grup A terdapat juga antigen protein $\mathrm{T}$ dan $R$ yang resisten terhadap tripsin. ${ }^{1}$

\section{b. Produk ekstraselular}

Streptococcus $\beta$ haemolyticus grup A dapat mengeluarkan sejumlah eksoprotein ekstraselular aktif yang bekerja sebagai toksin sistemik atau sebagai enzim invasif lokal seperti hemolisin yaitu streptolisin $\mathrm{O}$ dan streptolisin $S$, streptokinase, DNAse, proteinase seperti nikotinamid adenin dinukleotidase (NADase, adenosin trifosfatase (ATPase), neuraminidase, fosfatase, hialuronidase, dan lipoproteinase. Selain itu dikeluarkan juga eksotoksin pirogenik (eritrogenik) A, B, C. ${ }^{1,5}$

\section{Streptokinase}

Streptokinase adalah protein ekstraselular dengan berat molekul 46-kDa, terdiri dari 414 asam amino, diproduksi oleh semua strain Streptokokus grup A, dan berperan dalam patogenesis GNAPS. Hingga sekarang telah dikenal 9 genotipe streptokinase yang berkaitan dengan GNAPS seperti sak-1, -2, -6, dan -9. Pada binatang percobaan, hilangnya gen streptokinase dapat mengeliminasi bagian nefritogenik strain tertentu. ${ }^{2}$ Streptokokus grup A dapat memproduksi 2 jenis streptokinase imunogenik yaitu streptokinase yang dapat mengubah plasminogen menjadi plasmin dan streptokinase yang mengubah C3 menjadi C3a, suatu faktor kemotaktis. ${ }^{1,5,9}$

Streptokinase dikenal juga sebagai fibrinolisin yang merupakan spreading factor, ${ }^{2}$ dan berperan dalam penyebaran kuman melalui jaringan karena kemampuannya mengubah plasminogen menjadi plasmin. ${ }^{4}$ Plasmin akan mengaktivasi kaskade komplemen, menyebabkan pemecahan protein matriks ekstraselular, mencerna fibrin, dan menginduksi pelepasan vasoaktif bradikinin. Sebagai hasilnya, infeksi jaringan lunak oleh Streptokokus grup A akan cepat menyebar dan meluas. ${ }^{2,4,6}$

Streptokinase dapat juga berikatan dengan struktur glomerulus yang normal dengan afinitas yang berbedabeda untuk setiap strain. Streptokinase terikat erat dengan glomerulus, dan deposit streptokinase glomerular dapat dideteksi dengan teknik pewarnaan tertentu. ${ }^{2}$

\section{Streptolisin}

Streptokokus grup A dapat mensekresi 2 jenis hemolisin yaitu streptolisin $\mathrm{O}$ (oxygen-labile) dan 
sreptolisin S (serum-soluble). Keduanya dapat menghancurkan eritrosit, leukosit polimorfonuklear, trombosit, dan organela dengan cara membuat lubang pada membran sel. Streptolisin O bersifat imunogenik dan oxygen-labile, sedangkan streptolisin $S$ tidak imunogenik dan oxygen-stabile. ${ }^{1}$ Pemberian secara intravena pada binatang percobaan dapat menyebabkan kematian dalam beberapa detik akibat mekanisme toksik akut pada jantung. Streptolisin O berperan juga dalam patogenesis demam reumatik pasca streptokokus dan disekresi juga oleh Streptokokus grup C dan G. ${ }^{6,9}$ Streptolisin S dapat menginduksi pelepasan kandungan lisosom yang diikuti dengan kematian sel akibat pagositosis. Streptolisin S berperan terhadap beta-hemolisis sekitar koloni pada media agar darah. ${ }^{6}$

\section{Neuraminidase}

Pada GNAPS, neuraminidase streptokokus mempengaruhi imunoglobulin ( $\mathrm{IgG})$ dengan cara sialisasi (sialized), sehingga menjadi autoantigenik yang menjadi dasar terjadinya kompleks imun nefrotoksik. Imunoglobulin $\mathrm{G}$ yang bersifat autoantigenik akan menginduksi pembentukan kompleks imun komplemen yang akan mengendap di kapiler glomerulus, ${ }^{10,11}$ dan akan menstimulasi anti-IgG yang berperan dalam pembentukan krioglobulin. Peran patologik neuraminidase terbukti dengan terdapatnya asam sialat bebas dan aktivitas neuraminidase dalam serum pasien GNAPS, serta percobaan yang menunjukkan bahwa pemberian neuraminidase secara intravena akan menyebabkan infiltrasi leukosit ke dalam ginjal dan neuraminidase-treated leukosit diakumulasi di ginjal. Neuraminidase diproduksi juga oleh streptokokus galur non nefritogenik..$^{2,11}$

\section{Endostreptosin}

Endostreptosin adalah protein dengan berat molekul 40-50 kDa yang berasal dari sitoplasma sel streptokokus. Protein ini berperan untuk mereabsorbsi antibodi antiglomerular dari serum pasien GNAPS. Deposit endostreptosin pada membran basalis glomerulus mungkin suatu aktivator in situ terhadap jalur alternatif sistem komplemen dan secara imunologis berbeda dari enzim streptokokus yang lain atau komponen dinding sel. Endostreptosin dapat dideteksi dalam glomerulus pasien GNAPS stadium dini, dan tidak terdeteksi pada stadium lanjut. Peningkatan titer antistreptosin serum merupakan tanda diagnostik pada GNAPS. ${ }^{2}$

\section{Antigen kationik}

Protein kationik streptokokus grup A mempunyai afinitas tehadap polianionik membran basalis glomerulus. Antigen kationik ini berperan dalam terjadinya inflamasi glomerulus dan menyebabkan pembentukan kompleks imun in situ. Pada GNAPS, antibodi terhadap antigen kationik meningkat. ${ }^{2}$

\section{Eksotoksin pirogenik}

Sebagian besar Streptokokus grup A mengeluarkan satu atau lebih toksin yang disebut dengan eksotoksin pirogenik (eritrogenik) karena dapat menyebabkan demam. ${ }^{6}$ Eksotoksin pirogenik (eritrogenik) streptokokus (EPS, eksotoksin pirogenik streptokokus, streptococcal pyrogenic exotoxin) merupakan faktor virulensi. Meskipun sudah dikenal sekitar 10 jenis eksotoksin pirogenik, ${ }^{1}$ namun baru 3 toksin yang sudah diketahui karakteristiknya yaitu EPS A, EPS B, dan EPS C. EPS A merupakan toksin yang paling toksik di antara ketiganya dan dapat menyebabkan kematian pada binatang percobaan jika disuntikkan. Eksotoksin $B$ dapat juga menyebabkan nekrosis miokard dan kematian binatang percobaan. Eksotoksin A dan EPS $\mathrm{C}$ disebut juga dengan toksin eritrogenik karena dapat menyebabkan ruam seperti pada pasien skarlatina. Toksin ini dapat menyebabkan aktivasi limfosit $\mathrm{T}$ helper melalui cross-linking molekul MHC kelas II dan domain $\mathrm{V} \beta$ reseptor antigen pada subset limfosit $T$ dan menyebabkan pengeluaran interleukin IL-1 dan IL-2, tumour necrosis factor- $\alpha$ (TNF- $\alpha$ ) dan interferon- $\gamma$. Sitokin ini dapat menyebabkan berbagai manifestasi klinis seperti inflamasi, syok, dan gagal organ. Tidak seperti EPS A dan EPS C, semua strain Streptokokus grup A dapat memproduksi EPS B yang merupakan proteinase sistein. Eksotoksin B tampaknya lebih berperan pada kerusakan jaringan yang luas, ${ }^{6}$ dapat dideteksi di glomerulus pada $67 \%$ pasien GNAPS sedangkan pada non GNAPS hanya ditemukan 16\%. Titer antibodi terhadap EPS B meningkat pada GNAPS dan berbeda dengan pada pasien demam reumatik akut, demam skarlatina, dan orang normal. ${ }^{2}$

Streptokokus yang diisolasi dari pasien glomerulonefritis dapat mengeluarkan protein ekstraselular dengan berat molekul $46-\mathrm{kDa}$ dan tidak ditemukan pada galur 
yang berasal dari pasien tanpa glomerulonefritis. Protein yang berikatan dengan strain glomerulonefritis akan menjadi protein terikat plasmin (plasmin-binding protein) dan dikenal sebagai prekursor EPS B atau streptococcal proteinase zymogen. Protease atau superantigenik yang berikatan dengan eksotoksin-protease-plasmin dapat menyebabkan aktivasi sistem imun dengan memecah banyak faktor pejamu yang menyebabkan pelepasan mediator inflamatori aktif, faktor permeabilitas vaskular, dan fragmen aktif biologik dinding sel streptokokus. ${ }^{2}$

\section{Nephritis associated plasmin receptor}

Nephritis associated plasmin receptor (NAPlr) adalah suatu protein dengan berat molekul $43-\mathrm{kDa}$ yang diisolasi dari streptokokus nefritogenik. Protein NAPLr merupakan antigen yang terdapat dalam glomerulus pada stadium dini GNAPS. Protein NAPlr yang larut akan berikatan dengan glomerulus dan mempengaruhi plasmin teraktivasi (activated plasmin) yang mempunyai peranan penting pada proses inflamasi lokal. Dilaporkan NAPlr juga berkontribusi langsung terhadap aktivasi komplemen melalui jalur alternatif. Antibodi terhadap NAPlr dapat dideteksi dalam serum $92 \%$ pasien GNAPS dalam 3 bulan setelah awitan penyakit. ${ }^{2}$

\section{Hialuronidase}

Streptokokus grup A mengeluarkan enzim hialuronidase untuk merusak jaringan. Hialuronidase merupakan spreading factor yang bekerja memecah asam hialuronat dan dapat menyebabkan penyebaran infeksi sepanjang jaringan. Selama terjadinya infeksi terutama infeksi kulit, titer antibodi serum terhadap hialuronidase akan meningkat secara bermakna. ${ }^{2,6}$

\section{Peptidase C5a}

Peptidase C5a merupakan kemotraktan sel pagosit C5a dan terdapat pada semua sel strain Streptokokus grup A. ${ }^{5}$ Peptidase dapat merusak sinyal kemotaktik dengan memecah komponen komplemen $\mathrm{C} 5 \mathrm{a}$, sehingga menjadi inaktif.,

\section{Deoksiribonuklease}

Paling sedikit dijumpai empat bentuk deoksiribonuklease (DNAase) yang dihasilkan oleh Streptokokus grup A, yaitu DNAase A, B, C, dan D, tetapi DNAse $\mathrm{B}$ merupakan bentuk yang paling sering dijumpai dan yang paling imunogenik. Enzim ini akan menghidrolisis asam nukleat dan berperan penting dalam penyebaran faktor yang mencairkan pus atau eksudat kental. ${ }^{1,6}$

\section{Lipoproteinase}

Beberapa galur Streptokokus grup A mempunyai serum opacity factor (SOP) pada permukaannya, suatu lipoproteinase sensitif tripsin yang berperan dalam serologis spesifik terhadap tipe $M$ dan dapat digunakan untuk mengidentifikasi strain Streptokokus grup A. ${ }^{1}$ Enzim lipoproteinase dikenal juga sebagai faktor opasitas serum (serum opacity factor) karena menginduksi terjadinya opalosensi pada media pertumbuhan yang mengandung serum. Manfaat sesungguhnya belum diketahui tetapi ada korelasi kuat antara produksi enzim dengan tipe $M$ yang diproduksi strain penyebab infeksi kulit. ${ }^{6}$

\section{Nikotinamid adenin dinukleotidase, adenosin trifosfatase, fosfatase}

Nikotinamid adenin dinukleotidase (NADase), adenosin trifosfatase (ATPase), dan fosfatase merupakan enzim protease yang disekresi oleh streptokokus nefritogenik. ${ }^{1,6}$

\section{Patogenesis GNAPS}

Glomerulonefritis akut pasca streptokokus merupakan penyakit immune-mediated yang berhubungan dengan infeksi saluran nafas akut dan infeksi kulit oleh kuman Streptokokus grup A strain nefritogenik. Berbagai macam kandungan streptokokus atau produknya bersifat antigenik dan dapat menyebabkan proses imunopatologis yang menimbulkan glomerulonefritis, tetapi mekanisme yang pasti sebagai penyebab kerusakan ginjal masih diperdebatkan. ${ }^{2,3}$

Apabila pasien yang terinfeksi Streptococcus $\beta$ haemolyticus grup A nefritogenik memberikan reaksi terhadap antigen streptokokus dengan membuat antibodi. Reaksi antigen antibodi ini terjadi dalam sirkulasi atau in situ dalam glomerulus, menyebabkan reaksi inflamasi yang menimbulkan kerusakan ginjal. Reaksi ini dipicu oleh aktivasi plasminogen menjadi plasmin oleh streptokinase dan diikuti oleh aktivasi 
komplemen, pengendapan kompleks antigen-antibodi dalam glomerulus, dan ikatan antibodi antistreptokokus dengan molekul protein ginjal (mimicry protein) yang mirip antigen streptokokus.

Imunitas humoral oleh antigen streptokokus nefritogenik ditandai dengan pembentukan kompleks antigen-antibodi dan adanya deposit kompleks imun dalam glomerulus. Proses imun akan mengaktivasi komplemen melalui jalur klasik dan alternatif. Aktivasi melalui jalur klasik terutama terjadi pada fase permulaan dan akan diaktivasi oleh kompleks imun jika terjadi deposit IgG. Penelitian membuktikan bahwa aktivasi jalur alternatif juga terjadi, tampak adanya properdin glomerulus, deposit C3 yang mendahului IgG, bahkan C3 dapat ditemukan pada glomerulus tanpa IgG, dan pada fase akut GNAPS kadar C3 dan C5 serum sangat rendah. Selain itu terjadi juga aktivasi jalur komplemen terminal dan pembentukan kompleks C5-9 terminal. Kompleks komplemen terminal menggambarkan kemampuan untuk menstimulasi produksi substansia vasoaktif, enzim proteolitik, dan radikal oksigen reaktif, yang kesemuanya akan merusak integritas membran kapiler glomerulus. Fase dini GNAPS mungkin berhubungan dengan faktor nefritik C3 dan penurunan kadar C3 plasma. Faktor nefritik C3 merupakan antibodi terhadap konvartase C3 yang akan menginduksi aktivasi jalur alternatif yang diikuti dengan penurunan C3. ${ }^{2}$ Meskipun telah dikenal berbagai faktor streptokokus, tetapi baru beberapa konsituen somatik dan produk ekstraselular yang diketahui berperan dalam patogenesis GNAPS yaitu protein $M$, neuraminidase, endostreptosin (preabsorbing antigen), protein kationik (cationic proteins), streptococcal pyogenic exotoxin $B$, streptokinase, dan nephritis associated plasmin receptor. ${ }^{2}$

Sejumlah protein permukaan streptokokus dapat berikatan dengan membran basalis glomerulus (heparan sulfat, laminin, kolagen IV). Peranan protein $M$ dalam menginduksi kerusakan ginjal didukung oleh adanya reaksi silang antara protein $M$ dengan antigen membran basalis glomerulus. Antibodi antiglomerular terbukti bereaksi dengan protein M12 streptokokus. ${ }^{2}$ Protein $M$ berikatan secara langsung dengan antigen ginjal seperti komponen membran basalis glomerulus dan antibodi IgG bersirkulasi. Penyuntikan antigen protein $\mathrm{M}$ atau kompleks imunoprotein $\mathrm{M}$ ke dalam binatang percobaan dapat menyebabkan kerusakan ginjal. Protein $M$ juga berperan dalam progresivitas kerusakan glomerulus. ${ }^{4}$
Pada pasien GNAPS, terdapat peningkatan titer IgG terhadap fraksi $\mathrm{C}$ terminal protein $\mathrm{M}$ tetapi tidak pada fraksi $\mathrm{N}$ terminal. Ikatan IgG dengan bakteri merupakan hal yang penting dalam terjadinya GNAPS. Ikatan IgG dan endapan IgA sering ditemukan pada streptokokus nefritogenik. Fraksi Fc IgG dan IgA dapat berikatan dengan permukaan streptokokus grup A melalui protein $\mathrm{M}$ atau protein $M$-like. Fc reseptor streptokokus nefritogenik dapat menginduksi molekul anti-IgG dan dengan demikian berkontribusi terhadap patogenesis GNAPS dengan meningkatkan deposit kompleks imun di ginjal. ${ }^{2}$

Neuraminidase yang diproduksi streptokokus akan mengubah IgG autolog endogen menjadi autoimunogenik. IgG autoimunogenik yang dimodifikasi ini akan menstimulasi pembentukan antibodi terhadap IgG (anti-IgG), kemudian membentuk kompleks imun bersirkulasi dan mengendap membentuk deposit di glomerulus. ${ }^{3}$ Endostreptosin dapat dideteksi dalam glomerulus pasien GNAPS stadium dini, dan tidak terdeteksi pada stadium lanjut. Deposit endostreptosin pada membran basalis glomerulus mungkin suatu aktivator in situ terhadap jalur alternatif sistem komplemen. Protein kationik streptokokus grup A diketahui mempunyai afinitas tehadap polianionik membran basalis glomerulus. Antigen kationik menyebabkan pembentukan kompleks imun in situ dan berperan dalam terjadinya inflamasi glomerulus.

Toksin EPS B merupakan proteinase sistein dan berperan pada kerusakan jaringan. Pada GNAPS, titer antibodi EPS B meningkat dan EPS B dideteksi pada glomerulus $67 \%$ pasien GNAPS. ${ }^{2}$ Streptokinase mengubah plasminogen menjadi plasmin dan C3 menjadi C3a. Plasmin akan mengaktivasi komplemen dan menyebabkan pemecahan protein matriks ekstraselular. ${ }^{15,9}$ Protein NAPlr akan berikatan dengan glomerulus dan mempengaruhi plasmin teraktivasi (activated plasmin) yang mempunyai peranan penting pada proses inflamasi lokal. ${ }^{2}$ Beberapa teori yang dikemukakan mengenai patogenesis GNAPS adalah 1. Pembentukan kompleks imun bersirkulasi (circulating immune complex) dan kemudian terperangkap pada glomerulus, 2. Terdapat kemiripan molekul antara streptokokus dengan antigen ginjal, (misalnya jaringan glomerulus normal bertindak sebagai autoantigen dan bereaksi dengan antibodi bersirkulasi yang dibentuk terhadap antigen streptokokus), 3. Pembentukan kompleks imun in situ antara antibodi streptokokus dan antigen glomerulus, 4. Aktivasi komplemen secara 
langsung oleh deposit antigen streptokokus dalam glomerulus. ${ }^{2,3}$

\section{Sistem koagulasi}

Aktivasi sistem koagulasi terlihat dengan meningkatnya kadar kompleks fibrinogen dalam plasma, terjadinya hipo- atau hiperfibrinogenemia, penurunan faktor XIII, makroglobulin $\alpha-2$, dan aktivasi faktor XII. Fibrinolisis meningkat yang ditandai dengan peningkatan fibrinogen atau produk penghancuran fibrin (fibrin degradation product) dalam serum dan urin. Ekskresi produk melalui urin merupakan indikasi adanya degradasi deposit fibrin glomerulus. Pada GNAPS selalu didapatkan deposit fibrin dan antigen fibrinogen di dalam glomerulus. Kemungkinan juga terjadi aktivasi trombosit karena terjadi penurunan waktu hidup trombosit serta adanya faktor aktivasi trombosit dan faktor pertumbuhan trombosit. ${ }^{2}$

\section{Infiltrasi sel dan produksi sitokin}

Pada GNAPS terdapat hiperselular glomerular difus sebagai akibat akumulasi leukosit polimorfonuklear dan monosit, peningkatan sel intrinsik glomerulus, dan ekspansi patologis matriks mesangial. Proliferasi ini diinduksi oleh proliferasi sel endotel, sel mesangial, dan sel makrofag. Infiltrasi makrofag glomerulus dimediasi oleh komplemen kemotaktik dan oleh aktivasi antigen spesifik sel T. Superantigen streptokokus menyebabkan peningkatan reseptor $\beta$ sel T dan aktivasi sel T secara masif dengan pengeluaran limfokin sel T seperti IL-1 dan IL-6. ${ }^{2}$ Selain infiltrasi makrofag, terdapat juga infiltrasi neutrofil dan limfosit $T$ pada glomerulus, tetapi tidak ada infiltrasi limfosit B. Pada glomerulonefritis proliferatif aktif, terdapat monosit dan makrofag yang mengekskresikan antigen CD16 di dalam glomerulus dan urin dan jumlah sel ini berkorelasi dengan beratnya inflamasi glomerulus. Makrofag CD16 memproduksi sitokin proinflamatori tumor necrosis factor (TNF) dalam jumlah besar, sedangkan sitokin inflamatori IL-10 tidak diproduksi atau diproduksi dalam jumlah sedikit.

Sebagai respons terhadap antigen glomerular nefritogenik, terjadi aktivasi 2 subset sel T helper. Sel T helper-1 akan memproduksi IL-2 dan interferon gamma, mengaktifkan makrofag, dan menginduksi sekresi antigen $\mathrm{MHC}$, sedangkan sel T helper-2 akan mensekresi IL-4, IL-5, IL-6, ko-faktor proliferasi sel B, dan stimulan untuk produksi Ig. IL-1 potensial meningkatkan inflamasi glomerulus. Sitokin inflamatori (IL-4, IL-6, IL-10, IL-13, transforming growth factor $\beta)$ akan menurunkan sintesis IL-1 oleh makrofag dan menekan pembentukan radikal oksigen, nitrous intermediate, sekresi enzim proteolitik, dan ekspresi reseptor Fc. Imunoreaktivitas glomerulus terhadap IL-8 berkorelasi dengan infiltrasi neutrofil dan gambaran klinis GNAPS. Transforming growth factor $\beta 1, \beta 2, \beta 3$ berperan terhadap akumulasi komponen matriks mesangial termasuk kolagen, proteoglikan, dan fibronektin. Pada GNAPS, kadar IL-6 dalam plasma sebanding dengan perjalanan klinik. Sitokin TNF- $\alpha$ meningkat pasca fase akut, sedangkan kadar platelet derived growth factor selalu normal. Kerusakan atau aktivasi mesangial dapat dikontrol oleh inhibitor protease serin. Megsin yaitu salah satu kelompok inhibitor protease serin predominan dalam sel mesangial. $^{2}$

\section{Radikal bebas oksigen}

Pada GNAPS, kemampuan pertahanan antioksidan akan berkurang atau hilang dan dapat terjadi stress oksidatif berkepanjangan, meningkatnya kerentanan terhadap peroksidase lemak, dan lisis osmotik sel darah merah. Peroksidase lemak meningkat yang ditandai dengan peningkatan fragilitas osmotik sel darah merah, serta peningkatan kadar dialdehid malonil, glutation teroksidasi, dan hemoglobin. Selain itu pada GNAPS aktivitas enzim antioksidan seperti superoksida dismutase, katalase, glutation peroksidase, dan glutation-S-transferase menurun. Akibatnya kadar glutation reduksi akan sangat rendah dan sistem redoks glutation reduksi-glutation oksidase menurun atau tidak ada. ${ }^{2}$

\section{Pemeriksaan diagnostik}

Adanya infeksi streptokokus dapat diketahui dengan melihat peningkatan titer antibodi terhadap antigen yang berasal dari dinding sel dan produk ekstraselular kuman. Secara praktis, infeksi streptokokus diketahui dengan pemeriksaan antistreptolisin, antideoksiribonuklease B, antihialuronidase, antistreptokinase, dan antinikotinamid adenin dinukleotidase. Titer antistreptolisin dan anti-nikotinamid adenin dinukleotidase meningkat pada $80 \%$ pasien nefritis pasca faringitis, sedangkan titer antihialuronidase dan antideoksiribonuklease B meningkat pada 80- 
90\% pasien glomerulonefritis pasca infeksi kulit. Titer antibodi akan meningkat dalam 1-5 minggu setelah infeksi dan akan normal dalam beberapa bulan. Antibodi IgG terhadap fraksi C protein M streptokokus merupakan petanda diagnostik yang lebih realistis terhadap GNAPS sebab kadarnya tetap meningkat secara bermakna setelah kadar antibodi streptokokus yang lain sudah normal. Pada GNAPS, aktivasi sistem komplemen diketahui dengan mengukur kadar komplemen hemolitik (CH50) total, C3, dan C4. Lebih dari 90\% pasien GNAPS akan mengalami penurunan $\mathrm{C} 3$ dan $\mathrm{CH} 50$ sedangkan $\mathrm{C} 4$ normal atau sedikit menurun yang mengindikasikan adanya aktivasi melalui jalur alternatif. Kadar IgG dan IgM serum meningkat pada $90 \%$ pasien GNAPS. Kompleks imun bersirkulasi dan krioglobulin dapat dideteksi pada masing-masing $58 \%$ dan $66 \%$ pasien GNAPS. Antibodi antineutrofil sitoplasma dapat dideteksi pada $9 \%$ pasien GNAPS dan dihubungkan dengan beratnya penyakit seperti peningkatan kadar kreatinin dan pembentukan kresentik. ${ }^{2}$

Terdapat tiga pemeriksaan antibodi streptokokus yang lazim dilakukan yaitu pemeriksaan titer antistreptolisin $\mathrm{O}$ (ASO), titer anti-DNAse-B (ADB), dan uji streptozim. Jika memungkinkan dapat juga dilakukan pemeriksaan antihialuronidase. Antistreptolisin O dilakukan untuk mendeteksi infeksi Streptokokus $\beta$ hemolitikus grup A. Streptokokus grup A menghasilkan enzim streptolisin $\mathrm{O}$ yang dapat merusak sel darah merah. Oleh karena streptolisin O bersifat antigenik, maka tubuh memproduksi antistreptolisin $\mathrm{O}$ yang merupakan antibodi netralisasi. Antibodi ASO akan terdapat dalam darah satu minggu hingga dua bulan setelah awitan infeksi. Titer ASO yang tinggi tidak spesifik terhadap setiap penyakit infeksi streptokokus, tetapi mengindikasikan ada atau pernah terinfeksi streptokokus. Pemeriksaan ASO serial digunakan untuk mengetahui perbedaan antara fase akut dan konvalesen. Diagnosis adanya infeksi streptokokus sebelumnya diketahui dengan peningkatan titer ASO secara serial setiap minggu dan kemudian turun perlahan-lahan. Puncak peningkatan titer ASO terjadi pada minggu ketiga setelah awitan fase akut dan 6 bulan setelah awitan hanya 30\% yang menunjukkan nilai abnormal. Peningkatan lemak lipoprotein $\beta$ darah dapat menetraliser streptolisin $\mathrm{O}$ dan menyebabkan positif palsu pada pemeriksaan ASO. Antibiotik dan steroid dapat menekan produksi ASO. Nilai normal ASO pada anak 6 bulan -2 tahun adalah 50 Todd unit $/ \mathrm{ml}, 2-4$ tahun 160 Todd unit $/ \mathrm{ml}$, 5-12 tahun 170-330 Todd unit/ml, dan dewasa 160 Todd unit/ml. ${ }^{12}$ Titer ASO akan meningkat pada $75-$ 80\% GNAPS pasca faringitis dan pada 50\% GNAPS pasca impetigo. ${ }^{3}$

Pemeriksaan anti-DNAse-B (ADB) dilakukan untuk mendeteksi antigen Streptococcus $\beta$ haemolyticus grup A dan akan meningkat pada sebagian besar pasien GNAPS. Pemeriksaan ADB sering dilakukan bersamaan dengan pemeriksaan ASO dan dapat mendeteksi 95\% infeksi streptokokus. Jika keduanya diulang dengan hasil yang negatif, dapat disimpulkan bahwa penyakit tersebut tidak disebabkan infeksi pascastreptokokus. Pemeriksaan ASO lebih direkomendasikan daripada ADB tetapi kombinasi ASO dan ADB lebih baik daripada ASO sendiri atau ADB. Antibiotik dapat menurunkan kadar anti-DNAse-B. Nilai normal ADB pada anak prasekolah 60 unit, usia sekolah 170 unit, dan dewasa 85 unit.

Pemeriksaan streptozim merupakan uji skrining untuk mendeteksi sekaligus beberapa antibodi terhadap antigen streptokokus seperti DNAse, NADase, streptokinase, streptolisin $\mathrm{O}$, dan hialuronidase. Pemeriksaan ini mudah, cepat, dan tidak dipengaruhi oleh faktor yang menyebabkan positif palsu seperti pada pemeriksaan ASO. Kelemahannya adalah tidak dapat mendeteksi jenis antigen yang meningkat dan kadar antibodi dalam nilai border line meskipun sudah bermakna. Pemeriksaan streptozim lebih menguntungkan dibandingkan dengan ASO dan ADB. Nilai normal streptozim $<100$ unit. $^{12}$

Beberapa galur streptokokus tidak memproduksi streptolisin O sehingga lebih baik jika diperiksa lebih dari satu antibodi terhadap antigen streptokokus. Jika semua pemeriksaan serologis dilakukan, lebih dari 90\% infeksi streptokokus dapat dibuktikan. Pada keadaan awal, titer antibodi streptokokus belum meningkat sehingga dibutuhkan pemeriksaan serial dan pemeriksaan serial lebih bermanfaat dibandingkan dengan pemeriksaan tunggal. Peningkatan titer 2-3 kali menunjukkan adanya infeksi streptokokus. Perlu diketahui bahwa peningkatan titer antibodi terhadap streptokokus bukan berarti glomerulonefritis akut, karena diagnosis glomerulonefritis akut ditegakkan berdasarkan gambaran klinis dan perjalanan penyakit. ${ }^{3}$ Biakan usap tenggorok dan kulit dilakukan untuk menemukan kuman streptokokus, tetapi biasanya hasilnya negatif sebab umumnya pasien sudah mendapat antibiotik sebelumnya. ${ }^{3}$ 


\section{Penutup}

Struktur sel streptokokus grup A terdiri dari kapsul asam hialuronidat, dinding sel, fimbriae, dan membran sitoplasma yang menutupi sitoplasma. Berbagai macam kandungan streptokokus atau produknya bersifat antigenik dan dapat menyebabkan proses imunopatologis yang menimbulkan glomerulonefritis akut. Untuk mendeteksi adanya infeksi streptokokus, pemeriksaan laboratorium secara serial lebih bermanfaat dibandingkan dengan pemeriksaan tunggal.

\section{Daftar pustaka}

1. Shulman ST, Tanz RR. Streptococcus pyogenes (group A Streptococcus). Dalam: Long SS, Pickering LK, Prober CG, penyunting. Principles and practice of pediatric infectious diseases. Edisi ke-2. Philadelphia: Churchill Livingstone; 2003.h.716-8.

2. Sulyok E. Acute proliferative glomerulonephritis. Dalam: Avner ED, Harmon WE, Niaudet P. Pediatric nephrology. Edisi ke-5. Philadelphia: Lippincott Williams and Wilkins; 2004.h.601-13.

3. Makker SP. Poststreptococcal glomerulonephritis. Dalam: Kher KK, Makker SP, penyunting. Clinical pediatric nephrology. Edisi pertama. New York: MaGraw-Hll Inc; 1992.h.212-20.

4. Smith JM, Faizan MK, Eddy AA. The child with acute nephritic syndrome. Dalam: Webb N, Postlethwaite RJ, penyunting. Clinical paediatric nephrology. Edisi ke-3.
New York: Oxford University Press; 2003.h.367-80.

5. Todd JK. Streptococcal infections. Dalam: Gershon AA, Hotez PJ, Katz SL, penyunting. Krugman's infectious diseases of children. Edisi ke-11. Philadelphia: Mosby Inc; 2004.h.641-54.

6. Killian M. Streptococcus and enterococcus. Diunduh dari URL: http://www.fleshanbones.com/readingroom/pdfl410. pdf. Diakses November 2005.

7. Gerber MA. Group A streptococcus. Dalam: Behrman RE, Kliegman RM, Jenson HB, Nelson textbook of pediatrics. Edisi-17. Philadelphia: Saunders; 2004.h.870-9.

8. Bisno AL. Streprococcus pyogenes. Dalam: Mandell GL, Bennett JE, Dolin R, penyunting. Mandell, Douglas and Bernett's, Principles and practice of infectious diseases. Edisi ke-4. New York: Churchill Livingstone; 1995. h.1786-99.

9. Sharma S. Streptococcus group A infections. Diunduh dari: http://www.emedicine.com/med/topics2184.htm. Diakses November 2005.

10. McIntosh RM, Kaufman DB, McIntosh JR, Griswold W. Glomerular lesions produced in rabbits by autologous serum and autologous IgG modified by treatment with a culture of $\beta$-haemolytic streptococci. J Med Microbiol 1971;5:1-7.

11. Rodriguez-Iturbe B, Katujar VN, Coello J. Neuraminidase activity and free sialic acid levels in the serum of patients with acute poststreptococcal glomerulonephritis. N Engl J Med 1981;304:1506-10.

12. Flores JP. Diunduh dari: http://www.healthatoz.com/ healthatoz /Atoz/ency/streptococcal-antibody-tests-html. Diakses November 2005 